\title{
Mercury Recovery Results of Microwave Digested Tritium Facility Pump Oil
}

by

M. J. Whitaker

Westinghouse Savannah River Company

Savannah River Site

Aiken, South Carolina 29808

J. W. Clymire

This paper was prepared in connection with work done under the above contract number with the U. S. Department of Energy. By acceptance of this paper, the publisher and/or recipient acknowledges the U.S. Government's right to retain a nonexclusive, royalty-free license in and to any copyright covering this paper, along with the right to reproduce and to authorize others to reproduce all or part of the copyrighted paper. 


\section{DISCLAIMER}

This report was prepared as an account of work sponsored by an agency of the United States Government. Neither the United States Government nor any agency thereof, nor any of their employees, makes any warranty, express or implied, or assumes any legal liability or responsibility for the accuracy, completeness, or usefulness of any information, apparatus, product, or process disclosed, or represents that its use would not infringe privately owned rights. Reference herein to any specific commercial product, process, or service by trade name, trademark, manufacturer, or otherwise does not necessarily constitute or imply its endorsement, recommendation, or favoring by the United States Government or any agency thereof. The views and opinions of authors expressed herein do not necessarily state or reflect those of the United States Government or any agency thereof.

This report has been reproduced directly from the best available copy.

Available to DOE and DOE contractors from the Office of Scientific and Technical Information, P. O. Box 62, Oak Ridge, TN 37831; prices available from (423) 576-8401.

Available to the public from the National Technical Information Service, U. S. Department of Commerce, 5285 Port Royal Road, Springfield, VA 22161. 


\title{
MERCURY RECOVERY RESULTS OF MICROWAVE DIGESTED TRITIUM FACILITY PUMP OIL
}

\author{
Joseph W. Clymire and Michael J. Whitaker
}

\section{INTRODUCTION}

This report is a follow up of work done earlier this year and recorded in document WSRC-RP-97322. The scope of this document is to demonstrated the viability of digesting two non-radioactive Tritium facility pump oils, Welch Duoseal and Spindura, neat and spiked with low-level mercury to determine completeness of digestion and recoverability of mercury. As noted in document WSRCRP-97-322 a microwave digestion methodology was developed with CEM's ultimate digestion vessel system (UDV) and is the technique used for the follow up task of digesting the above mention pump oils for the preparatory step of cold-vapor mercury analysis.

All analytical development for this project was performed at TNX. The determination of the mercury concentration in each digested sample was by cold vapor atomic absorption. The instrument used was a Varian SpectrAA 800 with a vapor generation attachment. This flameless AA procedure is a physical method based on the absorption of radiation at $253.7 \mathrm{~nm}$ of mercury vapor. Organomercury compounds will not respond to the cold vapor atomic absorption technique, therefore, to acquire a total mercury value it is necessary for a complete digestion to oxidize and convert the organo-mercury species to the mercuric ion.

\section{Method Development}

CEM Ultimate Digestion Vessels (UDV) $\left(200^{\circ} \mathrm{C}, 1000 \mathrm{PSI}\right)$

The digestion of the Tritium facility pump oils was performed with a MDS 2000 ( 650 Watt) microwave digestion system and the UDV. A 0.5 gram oil sample was weighed into the UDV and $20 \mathrm{~mL}$ of nitric acid subsequently added. The vessel was sealed and placed in the microwave oven. The UDV allows the reaction to react at a maximum temperature of $200{ }^{\circ} \mathrm{C}$ and a maximum pressure of 1000 PSI. It was determined in the earlier work that a maximum pressure of 580 PSI was sufficient for complete digestion of oil matrix material. These same parameters were used in this follow up work. The temperature was not recorded due to a probe malfuction, however, the digestion process is controlled by the pressure limits rather than the temperature. 
After completion of the microwave digestion process, a minimum of two hours cooling period is required prior to opening the vessels to allow the pressure and temperature to drop to ambient conditions. Upon opening the vessel the dark green digestion solution was diluted to a final volume of $100 \mathrm{~mL}$. The dissolution remained clear with no signs of precipitation, which is evidence of complete digestion of the organic material. A summary of the microwave oven power, pressure, and timing sequencing are shown in table 1 below.

\begin{tabular}{|l|l|l|l|l|l|}
\hline Stage & 1 & 2 & 3 & 4 & 5 \\
\hline Power & $70 \%$ & $70 \%$ & $70 \%$ & $70 \%$ & $70 \%$ \\
\hline $\begin{array}{l}\text { Pressure } \\
\text { (PSI) }\end{array}$ & 35 & 100 & 200 & 340 & 580 \\
\hline Ramp Time & $5: 00$ & $5: 00$ & $4: 00$ & $4: 00$ & $4: 00$ \\
\hline Hold Time & $1: 00$ & $1: 00$ & $1: 00$ & $5: 00$ & $7: 00$ \\
\hline
\end{tabular}

Table 1

Summary of the Ultimate Digestion Vessel program

A range of mercury oil standards ( $10 \mu \mathrm{g} / \mathrm{g}$ to $1000 \mu \mathrm{g} / \mathrm{g}$ ) were spiked into the different oil matrix materials. After the digestion process they were analyzed and demonstrated acceptable mercury recoveries. A summary of the results are shown in table 2 and table 3 . In test number 1 and 2, the low recoveries are believe to be the result of incomplete digestion. These digestion solutions were a pale yellow color prior to diluting up to $100 \mathrm{~mL}$ rather than the dark green color. To insure complete digestion of the oil matrix material an adjustment in the timing sequence was made by increasing the hold time at the higher pressures. In test number 3 , after the timing sequence adjustment, the digestion is complete and the mercury recoveries improved considerably. $8 \mathrm{~mL}$ of $1000 \mu \mathrm{g} / \mathrm{L} \mathrm{Hg}$ standard was added to vessel \#11 and $20 \mathrm{~mL}$ of nitric acid. $8 \mathrm{~mL}$ of $1000 \mu \mathrm{g} / \mathrm{L} \mathrm{Hg}$ standard was added to vessel \#12, $0.4772 \mathrm{~g}$ of Spindura pump oil, and $20 \mathrm{~mL}$ of nitric acid. $8 \mathrm{~mL}$ of $1000 \mu \mathrm{g} / \mathrm{L}$ $\mathrm{Hg}$ standard was added to vessel \#13, $0.0362 \mathrm{~g}$ of $1000 \mu \mathrm{g} / \mathrm{g}$ Spex $\mathrm{Hg}$ oil, $0.4245 \mathrm{~g}$ of Spindura pump oil, and $20 \mathrm{~mL}$ of nitric acid. 0.4859 of the $1000 \mu \mathrm{g} / \mathrm{g} \mathrm{Spex} \mathrm{Hg}$ in oil standard was added to vessel $\# 15$ and $20 \mathrm{~mL}$ of nitric acid. 


\begin{tabular}{|c|c|c|c|c|c|}
\hline Vessel & $\begin{array}{c}\text { Approx. } \\
\mu \mathrm{g} / \mathrm{g} \\
\mathrm{Hg} \text { in Oil }\end{array}$ & Oil Type & $\begin{array}{c}\text { Theoretical } \\
\mu \mathrm{g} / \mathrm{L}\end{array}$ & $\begin{array}{c}\text { Actual } \\
\mu \mathrm{g} / \mathrm{L}\end{array}$ & $\begin{array}{c}\% \\
\text { Recover } \\
\mathrm{y}\end{array}$ \\
\hline TEST\#1 & & & & & \\
\hline Vessel\#1 & 18.73 & Spindura & 46.5 & 46.77 & 100.6 \\
\hline Vessel\#2 & 78.72 & Spindura & 36.0 & 23.70 & 65.8 \\
\hline Vessel\#3 & 17.50 & Welch & 8.2 & 6.22 & 75.9 \\
\hline Vessel\#4 & 62.20 & Welch & 57.8 & 47.83 & 82.8 \\
\hline Vessel\#5 & 60.64 & Conostan 20 & 57.0 & 43.21 & 75.8 \\
\hline TEST\#2 & & & & & \\
\hline Vessel\#6 & 48.77 & Welch & 51.6 & 47.01 & 91.1 \\
\hline Vessel\#7 & 37.59 & Welch & 35.0 & 30.03 & 85.8 \\
\hline Vessel\#8 & 64.53 & Spindura & 58.8 & 54.43 & 92.6 \\
\hline Vessel\#9 & 64.22 & Spindura & 64.4 & 50.30 & 78.1 \\
\hline Vessel\#10 & 58.03 & Conostan 20 & 53.8 & 43.41 & 80.7 \\
\hline TEST\#3 & & & & & \\
\hline Vessel\#11 & - & No Oil & 40.0 & 41.41 & 103.5 \\
\hline Vessel\#12 & - & Spindura & 16.0 & 16.13 & 100.8 \\
\hline Vessel\#13 & 78.58 & Spindura & 44.2 & 43.32 & 98.0 \\
\hline Vessel\#14 & 41.94 & .0235 & 47.0 & 46.76 & 99.4 \\
\hline Vessel\#15 & 1000 & Spex Oil & 38.9 & 37.5 & 96.5 \\
\hline TEST\#4 & & Std. & & & \\
\hline Vessel\#16 & 10.72 & Spindura & 10.4 & 10.17 & 97.8 \\
\hline Vessel\#17 & 10.88 & Spindura & 10.8 & 10.47 & 96.9 \\
\hline Vessel\#18 & 52.59 & Spindura & 51.8 & 48.94 & 94.5 \\
\hline Vessel\#19 & 46.42 & Spindura & 44.2 & 41.94 & 94.9 \\
\hline Vessel\#20 & 58.81 & Spindura & 54.8 & 52.10 & 95.1 \\
\hline & 5471 & & & \\
\hline
\end{tabular}

Table 2

Summary of mercury oil standards using ultimate digestion vessels. 
WSRC-RP-97-00889

\begin{tabular}{|c|c|c|c|c|c|}
\hline Vessel & $\begin{array}{c}\text { Approx. } \\
\mu \mathrm{g} / \mathrm{g} \\
\mathrm{Hg} \text { in Oil }\end{array}$ & Oil Type & $\begin{array}{c}\text { Theoretical } \\
\mu \mathrm{g} / \mathrm{L}\end{array}$ & $\begin{array}{c}\text { Actual } \\
\mu \mathrm{g} / \mathrm{L}\end{array}$ & $\begin{array}{c}\% \\
\text { Recovery }\end{array}$ \\
\hline \multicolumn{6}{|l|}{ TEST\#5 } \\
\hline Vessel\#21 & 44.30 & Welch & 45.2 & 44.08 & 97.5 \\
\hline Vessel\#22 & 13.13 & Welch & 12.8 & 12.87 & 100.5 \\
\hline Vessel\#23 & 18.14 & Welch & 17.0 & 16.81 & 98.9 \\
\hline Vessel\#24 & 15.38 & Welch & 14.8 & 14.37 & 97.1 \\
\hline Vessel $\# 25$ & 14.71 & Welch & 14.2 & 13.71 & 96.5 \\
\hline TEST\#6 & Digestion & Blanks & & & \\
\hline Vessel\#26 & 0 & $\begin{array}{l}20 \mathrm{~mL} \\
\mathrm{HNO}_{3}\end{array}$ & 0 & -0.44 & \\
\hline Vessel\#27 & 0 & $\begin{array}{l}20 \mathrm{~mL} \\
\mathrm{HNO}_{3}\end{array}$ & 0 & -0.51 & \\
\hline Vessel\#28 & 0 & $\begin{array}{l}20 \mathrm{~mL} \\
\mathrm{HNO}_{3}\end{array}$ & 0 & -0.56 & \\
\hline Vessel\#29 & $\overline{0}$ & $\begin{array}{l}20 \mathrm{~mL} \\
\mathrm{HNO}_{3}\end{array}$ & 0 & 1.43 & \\
\hline Vessel\#30 & 0 & $\begin{array}{l}20 \mathrm{~mL} \\
\mathrm{HNO}_{3}\end{array}$ & 0 & -0.59 & \\
\hline \multicolumn{6}{|l|}{ TEST\#7 } \\
\hline Vessel\#31 & 418.1 & Welch & 39.7 & 39.87 & 100.3 \\
\hline Vessel\#32 & 437.0 & Spindura & 40.3 & 42.00 & 104.2 \\
\hline Vessel\#33 & 291.1 & Welch & 26.3 & 25.71 & 97.7 \\
\hline Vessel\#34 & 274.1 & Spindura & 25.9 & 25.84 & 99.6 \\
\hline Vessel\#35 & 170.2 & Welch & 16.0 & 15.28 & 95.5 \\
\hline \multicolumn{6}{|l|}{ TEST\#8 } \\
\hline Vessel\#36 & 72.44 & Welch & 35.9 & 35.41 & 98.6 \\
\hline Vessel\#37 & 76.17 & Spindura & 37.1 & 36.46 & 98.3 \\
\hline Vessel\#38 & 40.72 & Welch & 19.8 & 19.33 & 97.6 \\
\hline Vessel\#39 & 38.66 & Spindura & 18.7 & 18.79 & 100.5 \\
\hline Vessel\#40 & 24.17 & Welch & 11.5 & 11.29 & 98.2 \\
\hline
\end{tabular}

Table 3

Summary of mercury oil standards using ultimate digestion vessels.

There was no evidence of cross contamination or absorption of mercury by the UDV Teflon liners demonstrated by the results of the nitric acid digestion blanks run between oil digestions and analyzed in the test \#6 phase. The UDV results suggest that the microwave digestion methodology reported in this document for the digestion of Tritium facility pump oils is a viable preparatory step for cold-vapor mercury analysis. 